\title{
Plaagdieren-enquête 2015
}

Geachte deelnemer,

Veel mensen komen in aanraking met plaagdieren in of om het huis. Toch is er maar weinig bekend over het aantal keren dat dit voorkomt, en hoe mensen daarmee om gaan. Daarom doet de Universiteit Utrecht onderzoek naar de mate waarin plaagdieren voorkomen in de Nederlandse huishoudens.

Deze korte vragenlijst dient als een eerste meting. Graag zouden we u een aantal vragen willen stellen, het invullen van deze vragen neemt 5 tot 10 minuten in beslag. Uw antwoorden blijven GEHEEL

ANONIEM, en worden alleen voor wetenschappelijke doeleinden gebruikt.

Niet iedereen zal onder plaagdieren hetzelfde verstaan. Om onduidelijkheid te voorkomen geven we u een lijst van dier- en insectsoorten die voor dit doel als plaagdieren kunnen worden beschouwd:

- $\quad$ knaagdieren (bijvoorbeeld: muizen, ratten, e.d.)

- $\quad$ vliegende insecten (bijvoorbeeld: muggen, vliegen, wespen, e.d.)

- $\quad$ kruipende insecten (bijvoorbeeld: kakkerlakken, vlooien, zilvervisjes, e.d.)

- $\quad$ vogels (bijvoorbeeld: duiven, kraaiachtigen, e.d)

- mollen

Bij voorbaat dank voor uw deelname.

\section{Algemene gegevens}

\section{Opleiding}

Volgt u op dit moment een voltijdsopleiding?

Markeer slechts één ovaal.

$$
\begin{aligned}
& \text { Ja } \\
& \text { Nee }
\end{aligned}
$$

\section{Woongebied}

Waar is uw woning gevestigd?

Markeer slechts één ovaal.
Dorp
Stad

$\bigcirc$ Platteland

\section{Leeftijd}

Wat is uw leeftijd?

\section{Opleidingsniveau}

Wat is uw hoogst afgeronde opleiding?

Markeer slechts één ovaal.

Basisschool

vmbo

havo

vwo 
$\bigcirc \mathrm{mbo}$

$\mathrm{hbo}$

universitair

Anders:

\section{Sekse}

Wat is uw geslacht?

Markeer slechts één ovaal.

Man

Vrouw

\section{Huisdieren}

Heeft u dieren in of om uw woning?

Markeer slechts één ovaal.

Nee

$\mathrm{Ja}$, ik heb een of meerdere huisdieren

Ja, ik houd beroepsmatig dieren in of om mijn woning

Ik heb zowel een of meerdere huisdieren als beroepsmatig vee

\section{7. (alleen voor studenten) Uitwonend}

Bent u een uitwonende student?

Markeer slechts één ovaal.

$\mathrm{Ja}$

$\mathrm{Nee}$

\section{Bouwjaar}

Wanneer is uw woning (ongeveer) gebouwd?

Markeer slechts één ovaal.

Voor 1960

Na 1960

Niet bekend

\section{Type huis}

In wat voor soort woning woont u?

Markeer slechts één ovaal.

\section{Rijtjeshuis / hoekhuis}

Flat of bovenwoning

Benedenwoning

Twee onder 1 kap

Veehouderij

Vrijstaand huis

Overig 


\section{Stellingen}

Hieronder vind $u$ een aantal stellingen die betrekking hebben op uw gezondheid, plaagdieren en plaagdierbestrijding. $U$ kunt telkens aangeven in hoeverre $u$ het eens bent met deze stelling, door een van de antwoordopties aan te vinken. De antwoordopties zijn voor elke stelling hetzelfde, die zijn namelijk:
A) Helemaal mee oneens
B) Deels mee oneens
C) Neutraal
D) Deels mee eens
E) Helemaal mee eens

\section{Gezondheid}

10. Ik volg de voorschriften van mijn huisarts omdat ze mijn gezondheid bevorderen

\section{Markeer slechts één ovaal.}

Helemaal mee oneens

Deels mee oneens

Geen mening

$\bigcirc$ Deels mee eens

$\bigcirc$ Helemaal mee eens

11. Ik heb een gebalanceerd eetpatroon

\section{Markeer slechts één ovaal.}

Helemaal mee oneens

Deels mee oneens

Geen mening

Deels mee eens

Helemaal mee eens

\section{Mijn gezondheid is belangrijk voor me}

Markeer slechts één ovaal.

Helemaal mee oneens

Deels mee oneens

Geen mening

Deels mee eens

Helemaal mee eens

\section{Ik sport regelmatig}

Markeer slechts één ovaal.

Helemaal mee oneens

Deels mee oneens

Geen mening 
Deels mee eens

Helemaal mee eens

14. Ik doe vaak dingen om mijn gezondheid te verbeteren

(e.g. sporten, vroeg naar bed gaan, gezond eten)

Markeer slechts één ovaal.

Chelemaal mee oneens

Deels mee oneens

Geen mening

Deels mee eens

Helemaal mee eens

15. Ziektes opgelopen via plaagdieren zijn ernstig

Markeer slechts één ovaal.

Helemaal mee oneens

Deels mee oneens

Geen mening

Deels mee eens

Helemaal mee eens

16. Ik schat de kans dat ik ziek word door plaagdieren in en om mijn woning hoog in.

Markeer slechts één ovaal.

Helemaal mee oneens

Deels mee oneens

Geen mening

Deels mee eens

Helemaal mee eens

17. Ik verwacht binnen het jaar ziek te worden door plaagdieren in en om mijn woning Markeer slechts één ovaal.

Helemaal mee oneens

Deels mee oneens

Geen mening

Deels mee eens

Helemaal mee eens

18. Het is waarschijnlijk dat ik ziek word via plaagdieren in en om mijn woning

Markeer slechts één ovaal.

Helemaal mee oneens

Deels mee oneens

Geen mening

Deels mee eens 
19. Een ziekte opgelopen via plaagdieren in en om mijn woning leidt tot gezondheidsproblemen. Markeer slechts één ovaal.

Helemaal mee oneens

Deels mee oneens

Geen mening

Deels mee eens

Helemaal mee eens

20. De kans dat ik ziek word via plaagdieren in en om mijn woning is groot.

Markeer slechts één ovaal.

Helemaal mee oneens

Deels mee oneens

Geen mening

Deels mee eens

Helemaal mee eens

21. Mijn zelfbeeld zou veranderen als ik ziek zou worden door plaagdieren in en om mijn woning Markeer slechts één ovaal.

Helemaal mee oneens

Deels mee oneens

Geen mening

Deels mee eens

Helemaal mee eens

22. Het oplopen van een ziekte via plaagdieren in en om mijn woning zou mijn leven sterk beïnvloeden

Markeer slechts één ovaal.

Helemaal mee oneens

Deels mee oneens

Geen mening

Deels mee eens

Helemaal mee eens

23. Ik maak me zorgen dat plaagdieren in en om mijn woning mij ziek maken.

Markeer slechts één ovaal.

Helemaal mee oneens

Deels mee oneens

Geen mening

Deels mee eens

Helemaal mee eens 
24. De gedachte dat ik ziek kan worden door plaagdieren in en om mijn woning is beangstigend Markeer slechts één ovaal.
Helemaal mee oneens
Deels mee oneens
Geen mening
Deels mee eens
Helemaal mee eens

\section{Plaagdierbestrijding}

25. Het bestrijden van plaagdieren voorkomt problemen in de toekomst

Markeer slechts één ovaal.
Helemaal mee oneens
Deels mee oneens
Geen mening
Deels mee eens
Helemaal mee eens

26. Het is lastig voor mij om plaagdieren te bestrijden

Markeer slechts één ovaal.

$\longrightarrow$ Helemaal mee oneens

$\longrightarrow$ Deels mee oneens

$\Longrightarrow$ Geen mening

$\bigcirc$ Deels mee eens

$\bigcirc$ Helemaal mee eens

27. Het is gunstig voor $\mathrm{mij}$ om plaagdieren te bestrijden

Markeer slechts één ovaal.
Helemaal mee oneens
Deels mee oneens
Geen mening
Deels mee eens
Helemaal mee eens

28. Ik weet hoe plaagdieren effectief bestreden kunnen worden Markeer slechts één ovaal.

Helemaal mee oneens

Deels mee oneens

Geen mening

Deels mee eens 
29. Als ik plaagdieren in of om mijn woning heb, dan is het mijn bedoeling om die te bestrijden. Markeer slechts één ovaal.

Helemaal mee oneens

Deels mee oneens

Geen mening

Deels mee eens

Helemaal mee eens

30. Plaagdierbestrijding is niet de moeite waard.

Markeer slechts één ovaal.

Helemaal mee oneens

Deels mee oneens

Geen mening

Deels mee eens

Helemaal mee eens

31. Het bestrijden van plaagdieren helpt in het beschermen tegen infectieziekten Markeer slechts één ovaal.

Helemaal mee oneens

Deels mee oneens

Geen mening

Deels mee eens

Helemaal mee eens

32. Plaagdierbestrijding kost mij te veel geld.

Markeer slechts één ovaal.

Helemaal mee oneens

Deels mee oneens

Geen mening

Deels mee eens

Helemaal mee eens

33. Als ik plaagdieren in of om mijn woning heb, dan ben ik van plan die te bestrijden.

\section{Markeer slechts één ovaal.}

Helemaal mee oneens

Deels mee oneens

Geen mening

Deels mee eens

Helemaal mee eens 
34. Het bestrijden van plaagdieren in en om mijn woning kost veel tijd.

Markeer slechts één ovaal.

Helemaal mee oneens

Deels mee oneens

Geen mening

Deels mee eens

Helemaal mee eens

35. Het is eenvoudig om plaagdieren te bestrijden

Markeer slechts één ovaal.

Helemaal mee oneens

Deels mee oneens

Geen mening

Deels mee eens

Helemaal mee eens

36. Als ik plaagdieren in of om mijn woning heb, dan ga ik die bestrijden.

Markeer slechts één ovaal.

Helemaal mee oneens

Deels mee oneens

Geen mening

Deels mee eens

Helemaal mee eens

37. Plaagdierbestrijding heeft vervelende consequenties

Markeer slechts één ovaal.

Helemaal mee oneens

Deels mee oneens

Geen mening

Deels mee eens

Helemaal mee eens

\section{Overlast plaagdieren}

38. Hoe zou u plaagdieren bestrijden?

Markeer slechts één ovaal.

Ik zou het zelf doen

Ik vraag de gemeente om het te doen

Ik huur een professioneel bedrijf in

Niet bestrijden

Anders: 
39. Voor het laatste deel van deze vragenlijst vragen we $u$ aan te geven hoe vaak $u$ in het afgelopen jaar de volgende plaagdieren in en om het huis heeft gehad?

Markeer slechts één ovaal per rij.

\begin{tabular}{|c|c|c|c|c|c|}
\hline & Nooit & Een enkele keer & Een aantal keer & Regelmatig & Vaak \\
\hline \multicolumn{6}{|c|}{ Knaagdieren (muizen, ratten e.d.) } \\
\hline \multicolumn{6}{|c|}{$\begin{array}{l}\text { Vliegende insecten (muggen, } \\
\text { vliegen, wespen e.d.) }\end{array}$} \\
\hline \multicolumn{6}{|c|}{$\begin{array}{l}\text { Kruipende insecten (kakkerlakken, } \\
\text { vlooien, zilvervisjes e.d) }\end{array}$} \\
\hline \multicolumn{6}{|c|}{$\begin{array}{l}\text { Vogels (duiven en kraaiachtigen } \\
\text { e.d.) }\end{array}$} \\
\hline Mollen & & & & & \\
\hline
\end{tabular}

40. Heeft u nog vragen en/of opmerkingen over deze vragenlijst?

Dit was het einde van de vragenlijst, wij willen u hartelijk bedanken voor de medewerking!

\section{Einde vragenlijst}

Mogelijkgemaaktdoor
E Google Forms 